\title{
Fluid Theologies: \\ Shifts and Changes of African Pentecostalism
}

\author{
Nomatter Sande \\ pastornomsande@yahoo.com
}

\begin{abstract}
The claim of 'being led by the Holy Spirit' has caused African Pentecostals to develop weak fluid theologies. The problem is exacerbated by the deepening of economic inequalities, unstable politics, and poverty. Qualitatively, this article used the response of African Pentecostals to Covid-19 in Zimbabwe as a case study to explore how African Pentecostal theologies lack systematic interpretations. The article concludes that the failure of African Pentecostals to speak coherently about Covid-19 shows the deep-rooted fluid nature of Pentecostalism as believers respond to the 'moves of the Spirit', resulting in shifting and changing theologies.
\end{abstract}

Keywords: Fluid theologies, African Pentecostalism, Covid-19, Pentecostal hermeneutics, led by the Spirit

\section{Introduction}

Since the emergence of classical Pentecostalism in Southern Africa and Zimbabwe in the $20^{\text {th }}$ century, the impact of the movement continues to be felt. According to Faimau and Lesitaokana (2018), Pentecostalism is the leading brand of Christianity in Africa. By the end of 2050, most Christians will be living in Africa (Müller 2020). In Zimbabwe, the movement has attracted millions of followers. Several factors account for why Pentecostalism is the most preferred form of Christianity in Zimbabwe. People select African Pentecostalism because of its claim to receive divine guidance for earthly problems. According to Ukah (2020a:431), 'over the past fifty years, scholars of Africa from different academic disciplines have argued, 


\section{Nomatter Sande}

described, and documented the myriad ways in which Pentecostal Christianity has infiltrated or permeated different strata of life and modes of living on the continent'. Of course, the multiple challenges experienced in Southern Africa have accelerated the spread of Pentecostalism. African Pentecostals are on record for claiming supernatural healing, prosperity, and divine protection for their congregations. However, it is one thing to claim these supernatural healings and another to deliver it during times of need. Fittingly, there is a need to understand African Pentecostal theologies in the context of pandemics. The unprecedented emergence of Covid-19 uniquely opened opportunities for displaying Pentecostal doctrines. Overarching in this article is the notion that the African Pentecostals' response to the 'move of the Spirit' gives them a fluid nature, manifesting in shifts and changes in theologies. This article defines the clause 'led by the Spirit' as being given information by the Holy Spirit which provides the basis for making decisions and taking action. The Holy Spirit directs the way in which the believer lives and at times, the information which comes from being 'led by the Spirit' is normally not logical.

Methodologically, this article qualitatively analyzed data gathered from social media, newspaper articles, news channels and text-based research. This article has five sections: The first section focuses on the Pentecostal hermeneutics as a starting point to understand how Pentecostals read and make sense of the Bible and the world around them. The second section gives a brief historical context of African Pentecostalism in Zimbabwe. The third section explores the impact of Covid-19 in Zimbabwe during the time of this article. The fourth section argues that the emergence of Covid-19 presents opportunities to understand shifts and changes of some Pentecostal theologies like divine healings, evils, science, and eschatology. The fifth section is a conclusion, arguing for fluid theologies within African Pentecostals. The future for a solidified systematic African Pentecostal theology is therefore oblique.

\section{Pentecostal Hermeneutics}

This article used Pentecostal hermeneutics to understand how African Pentecostals interpret the Bible and develop appropriate contextual theologies to meet the needs of people. The way in which believers read and interpret the 
Bible gives them their distinctiveness. According to Nel (2015:2; original emphasis), Pentecostal hermeneutics emphasizes 'the interrelationship between the Holy Spirit as the One animating scriptures and empowering the believing community'. In like manner, there are three interacting elements, namely the Holy Spirit, scriptures, and the believing community. The question is, To what extent does the claim of 'being led by the Holy Spirit' weaken how African Pentecostals develop and maintain their theologies? Pentecostals believe that all members have a calling for ministry. Identically, the believers' claim on the 'move of the Spirit' accounts for the multiple schisms within the African Pentecostal churches. According to Kgatle (2016), the manifestation of the Holy Spirit is a theological factor that is causing schisms for African Pentecostal churches. The members of African Pentecostal churches use Pentecostal hermeneutics to be equipped for ministry and witnessing in culturally appropriate ways (Rance 2009). Again, the desire for titles and autonomy, the notion that anyone can grow a mega-church, and the lack of theological training have aggravated complex fluid theologies.

Theology is contextual. Hence there is a possibility of a continuous development of diverse theologies. For instance, Zimbabwe's unstable politics, poverty, and deepening economic inequalities call for championing theologies to curb these contextual problems. According to Anderson (2016: 36), Pentecostalism has contextualized Christianity, mostly unconscious of the various theories behind the process, and mostly unnoticed by outsiders'. From a Pentecostal hermeneutics perspective, 'the Bible is interpreted as the product of an experience with the Spirit which the Bible describes in phenomenological language and leading to the expectation by modern-day believers that the Spirit would apply biblical truth and promises to their everyday experiences and circumstances' (Ervin 1985:33). Pentecostals view the Bible as God's word with specific words that guide their way (Nel 2015).

African Pentecostals lack frameworks for regulating their theologies because believers respond dissimilarly to the move of the Holy Spirit. African Pentecostals can learn from mainline churches, which seem to have kept their theologies coherently. The mainline churches prioritize documented methodological practices. For instance, the Roman Catholic theology argues that 'there can be no contradictions in the Bible nor real opposition between Biblical statements and the truths of philosophy, science or history because God is the author of scripture' (Olson 1999:133). To regulate theologies, African Pentecostals consider the suggestion by Lategan (2009:27) that 'the 


\section{Nomatter Sande}

interpretation of scripture is unthinkable without the supervision and control of ecclesial authority and the dogmatic tradition of the church'.

\section{Pentecostalism in Zimbabwe}

A brief overview of the Pentecostal trajectory in Zimbabwe is critical to put this article into context. The root of Pentecostalism in Zimbabwe is the Azusa Street Revival. An Azusa Street Pentecostals' evangelist, John Lake moved from the USA to South Africa. His work then spread to Zimbabwe. Historically, the spreading of Pentecostalism from South Africa did not happen overnight, but there are many experiences. In Zimbabwe, classical Pentecostalism was introduced around 1915 by laborers working in South African mines (Sande 2017). The Apostolic Faith Mission (AFM) in Zimbabwe is the mother of all Pentecostals. Over a period, Pentecostalism continued to grow and attracted many people. From 1980 to the 1990s, the Pentecostals were noticeably mushrooming everywhere. Notably, the reason for it varies, depending on the context, but an outstanding example in the early 1980s is that Pentecostals taught about breaking the spirit of poverty (Maxwell 1995). Overcoming the spirit of poverty was having a breakthrough in issues of indigenous businesses and self-reliance. According to Meyer (2004), Pentecostalism uses the spirit of capitalism to motivate congregations to economic growth.

The AFM in Zimbabwe has split, giving birth to other classical Pentecostals - the Apostolic churches therefore have their origin in the AFM. The prohibition of polygamy by the church led to the formation of the Mugodhi Apostolic Church. According to Gunda (2010), expulsions from the classical Pentecostals gave birth to several Apostolic churches. The formation of Apostolic churches like the Johane Masowe Chishanu Church and Johanne Marange Apostolic Church happened under the influence of Pentecostalism (Maxwell 2006). Besides giving birth to Apostolic churches, referred to as the African Indigenous Churches, the AFM gave birth to other large churches like the Zimbabwe Assemblies of God Africa Forward in Faith (ZAOGA FIF). Although ZAOGA FIF resembles the AFM in many ways, Togarasei (2010) argues that this church has distinguished itself as an elitist church, focusing on upward social mobility and empowerment. After the significant formation of ZAOGA and Family of God, other prominent classical 
Pentecostals include but are not limited to Hear the Word Ministries founded by Tom and Bonnie Deuschle.

Pentecostalism is not always homogeneous, as new forms of religious expression developed through schisms. For a better distinction from the classic Pentecostals, I call Pentecostal churches other than classical Pentecostals, 'Neo-Pentecostals'. Neo-Pentecostals branded themselves with a new wave of the prophetic mantle, supra miracles such as 'miracle money', 'miracle babies', 'miracle gold', and 'miracle weight losses'. Everything within Neo-Pentecostals is about miracles. Henceforth, Neo-Pentecostals are accused of replacing the role of humans to work by emphasizing the divine providence (Vengeyi 2011).

To put it differently, Neo-Pentecostals have managed to revise their spiritual expressions to meeting the declining socio-economic decline and political instability. Credit has been given to Neo-Pentecostals for building communities and hope in national crises (Biri \& Togarasei 2014). As an illustration, Neo-Pentecostals introduced religious artefacts to aid the 'faith' of people to receive their miracles in healings and deliverances. Neo-Pentecostals' prophets sell oil, towels, prophets' pictures, and payment to have one-on-one meetings with the prophet (Biri 2012). Nonetheless, onlookers and critics feel that these artefacts are borrowed from the indigenous culture to win gullible believers.

In Zimbabwe, the impact of Pentecostalism is spreading to mainline churches, forming charismatic ministries. According to Kangwa (2016:573), 'the spread of Pentecostal-churches is changing the Christian landscape in Africa. In the process mainline churches, including the Roman Catholic Church, are getting transformed'. The United Methodist Church in Zimbabwe has embraced charismatic religious expressions. The Roman Catholics and Anglican church have been practicing Pentecostal rituals under protest for a long time, although most mainline churches now allow charismatic groups. Overall, the Pentecostal religious landscape of Zimbabwe is shifting and changing rapidly. Under those circumstances, the challenges of fluid theologies are inevitable. 


\section{An Overview of the Coronavirus in Zimbabwe}

In August 2021, when this article was written, it has been over 19 months since the emergence of Covid-19. This pandemic allegedly started in Wuhan, China (UNDP 2020). One way or the other, it has exposed the vulnerability of humanity. Pandemics are the proof that humanity does not have it all figured out. The increased death of people made those in authority lockdown all sectors of life, and for many people, life came to a standstill. Zimbabwe is a landlocked country with a population of over 16 million people (ZIMSTAT 2019). The statistics of Covid-19 cases are 117,258 and about 3,950 deaths (Worldometer 2021). However, these statistics could be on the rise because there are new strains and mutations of the virus.

Politically, the Zimbabwean government complied with regulations and lockdowns recommended by the World Health Organization (WHO) (Public Health 2020). The observation of these regulations is not easy. Zimbabweans are not keen on following these regulations. To deal with the devastation of Covid-19, the government introduced curfews and imprisonment to those who break the regulations. A possible reason is that Covid-19 started when Zimbabwe was going through a time of political instability and economic meltdown. Zimbabweans are living in abject hunger (UNDP Zimbabwe Report 2020). The impact of Covid-19 has exacerbated the problems of the medical fraternity, which is suffering from brain drain, a lack of medicines, and the absence of hospital equipment. A point often overlooked is that Zimbabwe cannot deal with an ever-increasing number of patients suffering from the virus. Self-medication through indigenous herbs has become popular. The availability of herbs and some indigenous knowledge systems have seen many households use herbal concoctions like lemons, garlic, ginger, zumbani/Lippia javanica, and steaming. There are contestations about the effectiveness of herbal concoctions and steaming.

The discovery of scientific vaccines has not given hope to Zimbabweans. From a social perspective, people view vaccines with suspicion. This can be traced back to the fact that Zimbabweans are still bitter about the issue of colonialization. They view the West as bad people, bringing vaccines to test in Africa. Historically, the West used black people to test their medicines. For instance, in 1932, 600 African American men from Macon County Alabama were enlisted to take part in a scientific experiment on syphilis (McVean 2019). Social media perpetuated several 
conspiracy theories, which have made many Zimbabweans look down upon vaccines. Additionally, the social media in Zimbabwe have provided the population with an overload of information about Covid-19. Social media like WhatsApp, Facebook, television, and radio are easily accessible in this country.

\section{African Pentecostals Shifting and Changing Theologies}

Religious perspectives about Covid-19 have emphasized the challenge of the relationship between science and religion and the fluidity of some theologies, underpinning forms of Christianity like African Pentecostalism. Africans prides themselves in understanding the spiritual realm. Sande and Maforo (2021:1) succinctly argue that 'the church continues to be the primary place where economic, social, psychological and spiritual needs of the people are met'. Emile Durkheim argues that religion provides the meaning of life, cohesion, and hope for individuals and society (Durkheim 1995.). According to Lumberas and Oviedo (2020), Durkheims' functionalist theory of religion argues that if religion fails to proffer a positive service to society, then it should not be allowed in a society. Durkheim argues that 'religion is a societal glue' (Vander Zanden 1988:378).

The perspective of African Pentecostals about Covid-19 can reinforce and create social control and maintain social solidarity. As suggested by the functionalist theory, that religion has a role in society, the African Pentecostal theologies should be providing solutions to pandemics. However, the question is, To what extent has certain African Pentecostals' theologies such as divine healing and eschatology impacted believers' views about Covid-19 and their lived experiences. Broadly, African Pentecostalism emphasizes divine healings, the power of the Holy Spirit, and spiritual gifts. In order to answer the question about fluid theologies in the context of Covid-19, this article explores and discusses a few African Pentecostals' responses in Zimbabwe.

\section{Covid-19 as an Instrument for Demonstrating the Divine Healing}

Divine healing is one of the most distinctive traits of African Pentecostalism. African Pentecostal preachers encouraged their believers that God would make them safe during the pandemic. Many Zimbabweans are angry because 


\section{Nomatter Sande}

churches are failing to comply with Covid-19 restrictions (NewsdzeZimbabwe 2021). Broadly, Christian believers in some parts of Africa are in conflict with authorities about limited gatherings to combat the spread of Covid-19 (Kowalczyk, Roszkowski, Montane, Pawliszak, Tylkowski, \& Bajek 2020). The reasons for the failure of compliance by African Pentecostals to follow WHO regulations for reducing the spread of the virus, are based on their doctrines. African Pentecostals believe that the power of the Holy Spirit manifests in protecting believers. Prophet Emmanuel Makandiwa, the founder of the United Family International Church, assured his congregations that they are safe from the virus. Makandiwa claimed that the safety would come through prayer and divine protection. He boasted that 'you will not die because the Son is involved in what we are doing - the freedom that no medication can offer' (Kirby, Taru, \& Chimbidzikai 2020). This declaration by Makandiwa shows how African Pentecostal leaders are over-spiritualizing pandemics. The problem of over-spiritualizing pandemics is putting believers at risk by not encouraging them to act wisely. Pentecostal churches 'aspire, even claim, to reconstruct religion as a technology that responds to the daily needs and experiences of spiritual and physical insecurity which many Africans confront on a daily basis' (Ukah 2020b:333). It is high time that African Pentecostals revisited and developed a divine healing theology that encompasses rational choices.

Something that helped this article, was to investigate the previous behavior of African Pentecostals in the face of pandemics, as well as the lessons that were learned. Historically, Pentecostals are on record for not cooperating with scientific solutions for pandemic diseases like AIDS. According to Sande (2016:35), 'the Pentecostal hermeneutics embedded in gifts of the Holy Spirit, especially the gift of healing, is problematic when it comes to the HIV and AIDS pandemic. Rather, the over-emphasis of divine healing by Pentecostal movements and the African Indigenous Churches have brooded Antiretroviral Therapy defaulting candidates'. There is always a way in which the divine healing instruction, preached within African Pentecostalism side-lines the scientific medicines. Thus, in African Pentecostalism, more theological development targeting the nexus between divine healing, science, and pandemics is needed. The problem is where to draw a line when African Pentecostal members of the clergy assert that the Holy Spirit leads their oracles and declarations. 
In Zimbabwe, African Pentecostals' clergies are at risk to succumb to Covid-19. According to Chikwanah (2021), the rise of Covid-19 deaths in Zimbabwe are causing pastors to balance conducting 'funerals and being in ministry with grieving church members with the ever-present danger of contracting the virus and affecting their families'. Some pastors and leaders, regardless of knowing the challenges of the virus, continued performing rituals like weddings, funerals, and hospital visitations. The pastoral ministry and its expectations were a trap to pastors. Regardless of the context, the work of the clergy remains critical during a pandemic. According to Sande and Maforo (2021:2), in the Zimbabwean context, 'pastoral ministry is a product of both pastoral theology and practical theology'. An interesting comment about pastors concerning Covid-19 by Rev Forbes Mutanho of the United Methodist Church shows that 'COVID-19 does not respect our pastoral calling...Clergies are not classified as front-line personnel... when people die...they need dignified burials graced by pastors' (Chikwanah 2021). Such comment shows how society can put pastors in complex challenges during a pandemic.

It is therefore paramount to investigate how Pentecostal pastors, believing in the power of the Holy Spirit, react on the pandemic. Pentecostals preach about their power over snakes, scorpions, and even viruses. They really want to prove their power over viruses. The classical Pentecostal churches like the AFM in Zimbabwe (both factions of the church) used their secretariat to remind the people to observe the regulations stipulated by the government. According to empirical research conducted concerning the role of Pentecostal church leaders during this pandemic, Pavari (2021:7) has found that some 'leaders have also been instrumental in taking care of Pastors and the underprivileged members of the church and society. There is a need to increase strictness in churches towards following health guidelines as some members have continued to stick to old ways'.

\section{Fumigating Covid-19 with Spiritual Warfare}

African Pentecostals prescribe spiritual warfare as a fumigator for the virus. The use of spiritual warfare idioms serves to demystify the impact of the pandemic. Covid-19 is portrayed more as a 'spiritual force of evil' than a biomedical disease in this context. African Pentecostals claim that the battle is between God and the devil's agents through spiritual warfare perspectives. While the president of Zimbabwe, Emmerson Mnangagwa did not openly 


\section{Nomatter Sande}

comment on religious ideologies about the pandemic, his counterpart, President Magufuli of Tanzania argued that the 'Coronavirus is a devil, therefore, cannot survive the blood of Jesus, it will burn' (Bariyo \& Parkinson 2020). Once a virus is in the spiritual realm, it makes the WHO guidelines weak. African Pentecostal believers would instead enlist their names to fight the virus with prayer, rather than social distancing, masking, and the washing of hands. To the African Pentecostals, everything is spiritual. It implies that all the solutions for the pandemic are brewed in the spiritual realm.

African Pentecostal practitioners resolve to praying and fasting to destroy the 'evil spirit of corona' (The Conversation n.d.). Ultimately, to the devout Christians, the closure of churches due to the pandemic is viewed as an act against their faith and a sign of glorifying the devil (Halbfinger 2020). Accordingly, the focus on prayer by Africa Pentecostals provides militarized idioms and frameworks to respond to mundane and extraordinary events and Covid-19 is no exception. African Pentecostals' spiritual idioms demonstrate a sense of 'exceptionalism'. It is easy for these believers to think that though they are in this world, they belong to another world because of the power of prayer. However, African Pentecostal clergy should consider that idioms of divine protection can be catastrophic during a pandemic. The problem of 'exceptionalism' and spiritual protection instils a level of complacency that causes believers to be non-compliant with regulations and protocols for preventing the spread of Covid-19.

In cases where believers die because of the virus, prayer is used as an outlet to vent and soothe the troubled soul. The impact of the virus results in psychological pain and distress (Hong \& Handal 2020). The fact that loved ones are dying of Covid-19, brings anxiety and fear, even thoughts about one's own death. Thus, the invocation of spiritual warfare in dealing with the pandemic, is unethical and in fact a violation of human rights. In some disasters, spiritual warfare can work. Can it be correct that African Pentecostals are not open-minded enough to deal with the social problems bedeviling Zimbabwe? The quick answer is 'No'. African Pentecostals have helped during the cyclone Idai, which hit Chimanimani and Chipinge, while the church took part in proffering solutions to help the traumatized and displaced. The problems of Africa are continuing to soar on a daily basis. Morsy, Balma, and Mukasa (2020:24), as part of the African Development Bank, postulate that 'the pandemic will slow Africa's economic growth and 
exacerbate extreme poverty...In particular, the continent could record an increase in the rate of extreme poverty by $2.14 \%$ or $2.84 \%$ under the baseline or worst-case scenarios, respectively, which translates to an additional 28.2 million or 37.5 million people sliding into extreme poverty'. More strategies are therefore needed to enhance the intersection of science and religion.

\section{Covid-19 as an Eschatological Announcement}

African Pentecostals interpret the meaning of pandemics and epidemics in eschatological terms. Compounded in the African worldview, diseases do not simply happen, but measure and reflect the end times. Covid-19 is interpreted, using biblical allusions, to refer to the 'mark of the beast'. African Pentecostals use scriptures which talk about eschatology like the book of Revelation, specifically Revelation 13 which refers to the beast coming out of the sea. African Pentecostals argue that the emergence of Covid-19 marks the end of the world. According to Ukah (2020b:454), some Pentecostal leaders have claimed that the pandemic is a forerunner of the 'end-time, a prelude to the second coming of Jesus Christ. Pentecostals have been preaching this message of end-time as a stable and staple doctrine for several decades now'. Revelation 13 is interpreting a time when the anti-Christ will mark everyone under his reign. The discovery of the vaccine, especially the purported structure of the medicine, is mirrored as a microchip used to trace humanity. The vaccine is believed to be the 'mark of the beast'. During a sermon on YouTube, Prophet Makandiwa declared that 'I and my family are ready to die resisting the government if they come with any initiative of vaccinating us against Covid-19' (Makandiwa 2020a). The spirit of the anti-Christ is dreaded and is viewed as a period where everyone is under the control of their government.

Christianity is looking forward to the end times as it marks the harvesting of spiritual achievements on earth. Believers are willing to die or do anything which makes them safe from failing to make it to the next life. The challenge is that the doctrine of eschatology is complex, and many Christian denominations subscribe to diverse beliefs. The complication to apply to it is coming up with a comprehensive approach to explaining the source of viruses. Therefore, African Pentecostals cannot confidently claim that the havoc caused by pandemics is a sign of the end times. I suggest that there should be a way of prosecuting spiritual leaders who peddle misinformation about this pandemic. For example, labeling a pandemic like Covid-19 as a 


\section{Nomatter Sande}

hoax, is violating human rights and choices for gullible believers. Pastor Chris Oyakhilome, the leader of Christ Embassy of Nigeria with branches across the world, including Zimbabwe, maintained that the Covid-19 virus is a hoax and a plot of the West to destroy Africans. He claimed that the pandemic is nothing but a 'Ghost of the West', packaged in a 5G technology (Ibrahim 2020; original emphasis). Such thinking is informed by fear that the world superpowers want to reduce the worlds' population. Oyakhilome believes that $5 \mathrm{G}$ technology is a secret weapon of the Illuminati occultism, which aims to transform humanity into human machines (Oyakhilome 2020). The Illuminati is believed to be people who control the capital and technology in the West. Based on the above, this article argues that the failure of African Pentecostals to accommodate science, is because of their theologies which suspect certain technology as evil.

\section{Covid-19 as Evil Curses Promised}

With regards to pandemics, religions should be counted as a resource for controlling risks, illness, and the pandemic itself. The Bible contains some elements about dealing with pandemics. African Pentecostals explain the source of the pandemic as a promised evil, referring to the Bible. Listening to Pentecostal sermons, messages, and prayer content, indicate a belief that Covid-19 was sent to punish the sinful world. Theologizing on some biblical cases by African Pentecostals indicates that Covid-19 is a necessary evil to help humanity repent and come back to God.

Understanding the pandemic as sent by God, implies that he is vengeful to his people. Some African Pentecostals encouraged their members to follow the WHO regulations to reduce the spread of the virus. African Pentecostals favored the guidelines which have similar patterns like those found in the Bible. First, 'stay home' during disasters: People were called upon to stay home until the disaster is over. The reference is Genesis 6-7, where God sent the flood and he advised Noah and his family to stay home to be safe from disaster (Gn 7:6-7). In Genesis 29, Abraham obeyed the 'stay home' instruction until the disaster of Sodom and Gomorrah was over. After the disaster, Abraham returned to the place where he was before the disaster occurred (Gn 19:27-28). In another setting, God instructed the children of Israel to 'stay home' to escape the death that was coming upon them in Egypt. The instruction was to drop hyssops in blood and smear on the doorposts and stay home overnight (Ex 12:23). Even in wartime, 'stay home' 
was advised: During the invasion of Jericho, Rahab and her family stayed home to avoid death (Jos 2:1-20). The blood of those who would risk straying outside their homes, was upon them, and it was their responsibility (Jos 2:1719). The prophet Isaiah warned the children of Israel to stay home and hide from the wrath of God because God was punishing their sins (Is 26:20-22). Another instruction to deal with disasters was to 'flee', as noted in Genesis 19:1-29 where God punished Sodom and Gomorrah. Lot and his family were ordered to flee the city to escape the destruction (Gn 19:1-29). Therefore, the 'stay home' instruction used in the Bible is still adequate to managing the spread of Covid-19.

Prophecy is critical to African Pentecostalism, especially the neoPentecostals in Zimbabwe. Likewise, prophets in Zimbabwe claimed to have seen the coming of the pandemic long before it struck the country and warned the people like Isaiah. Pentecostals regard themselves as a people with the ability to transverse the future and warn people. On November 20, 2016, Prophet Makandiwa and his followers gave accurate details about Covid-19, stating that the virus was "more deadly than HIV/AIDS and cancer[. It would be a source] coming from the sea [and it was going to be] very aggressive' (UFIC n.d.). Further, in 2017, exactly two years, ten months, and 24 days after the prophecy was given, Makandiwa declared that his prophecy was fulfilled (Makandiwa 2020b). The only critique of the prophecy of Makandiwa is not whether the prophecy was accurate or not, but how the prophecy has helped during the pandemic. Like Isaiah who warned people to 'stay home', the question is to what extent does the prophets' prophecies aid nonspiritual activities like 'maintain a safe distance', 'wash your hands regularly', and 'stay home'.

Second, 'quarantine' was used in the Bible to isolate those who contacted infected people. The existing 'quarantine' method to avoid the spread of Covid-19 was already practiced in the Bible. According to Leviticus 13, people with infectious diseases were quarantined for 14 days to prevent more outbreaks. For instance, Miriam isolated because of her leprosy until she recovered (Num 12). Quarantine is a form of 'social distancing' which helps to reduce the spread of an illness or pandemic. The reason for social distancing is that in times of pandemics, anyone can be a carrier of the virus.

The shutdown of physical meetings caused Pentecostal churches to use online worship. In terms of online worship, Pentecostal churches were 


\section{Nomatter Sande}

ahead in Africa when using social media. Most churches have television stations where they broadcast their services. According to Mujinga (2021: 267), 'Pentecostal churches embraced the use of technology (television, internet facilities, print media and cell-phone beyond the pulpit)'. Facebook plays a critical role in providing health and wellbeing to the people of faith through sharing scriptures (Kgatle 2018). Also, the stations are hubs for missions where congregations in the diaspora can connect with what is happening in Zimbabwe. Some churches would make believers pay specific amounts to access the Zoom platforms and generate revenue for the ministry. Due to Covid-19, several businesses closed and many reduced salaries, affecting the church's tithes and offerings (Pavari 2021). Socio-economic challenges might be causing African Pentecostals to fail to quarantine.

Third, the WHO guidelines to 'sanitize and wash hands' mirrors the concept of hygiene in the Bible. Moses advised the Israelites to wash their hands to avoid contaminating others. According to Leviticus 15:7-8, anyone having unusual bodily discharging was considered unclean, even their clothes. The solution was to rinse their hands in water, bath, and wash their clothes. In some cases, the clothes of those infected with the illness were burned (Lev 13:53-56). In the case of earthenware, the Israelites were instructed to break them (Lev 15:12). Therefore, the Bible has 'stay home', 'quarantine', and 'wash hygiene' as tools to control pandemics and destructions - therefore African Pentecostals must keep them.

\section{Conclusion}

This article concludes that in many ways, African Pentecostals are appreciated by people for their creative theological solutions to meeting the needs of the people. The Zimbabwean context is shrouded with unstable politics, poverty, and deepening economic inequalities. African Pentecostals' claim that being filled by the Spirit, anoints the believer to curb their problems, has made the movement(s) become the fastest-growing Christian movement in Southern Africa, commanding millions of members and hundreds of thousands of new members yearly. However, the problem of the claim of 'being led by the Holy Spirit' has caused African Pentecostals to develop weak theologies. Equally, this is exacerbated by the African Pentecostal hermeneutics, which calls for a literal interpretation of scriptures, 
aided by the leading of the Holy Spirit. This article showed the fluid nature of African Pentecostalism by exploring the movements' response to the pandemic. To African Pentecostals, the unprecedented emergence of the virus may present an opportunity to demonstrate the efficacy of their spiritual gifts. However, instead, it showed a fluidity in their theologies. This article indicates that the African Pentecostal landscape employed shifts and changes in their theologies. For instance, African Pentecostals interpreted Covid-19 as a virus which would be healed divinely - as the devil's force which can be fumigated by prayer and fasting; as promised evil curses sent by God to make people repent; announcing the end times; vaccines as micro-chips for the 'mark of the beast' (Rev 13); and as a hoax, a plot of the West to reduce black Africans.

Such fluid theologies in each context affect the daily experiences of followers during a pandemic, causing less uptake of scientific vaccines. In Zimbabwe, African Pentecostals' failure to speak coherently about the pandemic, shows a deep-rooted shifting and changing theologies. In some cases, it results in being ethically questionable, especially when they violate human dignity and put believers at risk during the pandemic. Any theological interpretations in the context of pandemics affect the followers' lived experiences. Further, multiple schisms, a lack of theological training, a desire for titles and autonomy, and the notion that anyone can grow a mega-church have aggravated complex fluid theologies. Thus, African Pentecostals have fluid theologies which continue to be reshaping their future. The future for a solidified systematic African Pentecostal theology is oblique.

\section{References}

Anderson, A.H. 2016. Contextualization in Pentecostalism: A multicultural Perspective. International Bulletin of Mission Research 41, 1: 29-40. Bariyo, N \& J. Parkinson 2020. Tanzania's leaders urge people to worship in throngs against coronavirus. The Wall Street Journal. April 8, 2020. Available at: https://www.wsj.com/articles/tanzanias-leader-urgespeople-to-worship-in-throngs-against-coronavirus-11586347200. (Accessed on July 12, 2021.) 
Biri, K. 2012. The silent echoing voice: Aspects of Zimbabwean Pentecostalism and their quest for power, healing and miracles. Exchange 34, 4: 1-14.

Biri, K, \& L. Togarasei 2014. But the one who prophecies, builds the church. In Chitando, E., MR. Gunda \& J. Kugler (eds.): Prophets, profits and the Bible in Zimbabwe: Festschrift for Aynos Masotcha Moyo. Bamberg: Bamberg University Press.

Chikwanah, E. 2021. COVID-19 deaths complicate pastor's calling. U.M. News. February 3, 2021. Available at: https://www.umnews.org/en/ news/COVID-19-deaths-complicate-pastors-calling. (Accessed on August 7, 2021.)

Durkheim, E. 1995. The elementary forms of the religious life. Fields, K. (trans.). New York: Free Press.

Ervin, H.M. 1985. Hermeneutics: A Pentecostal option. In Elbert, P. (ed.): Essays on apostolic themes: Studies in honour of Howard M. Ervin. Peabody: Hendrickson.

Faimau, G. \& W.O. Lesitaokana (eds.) 2018. New media and the mediatisation of religion: An African perspective. Newcastle Upon Tyne: Cambridge Scholar Publishing.

Gunda, MR. 2010. A critical analysis of the survival and relevance of postcolonial African initiated (apostolic) churches. In Togarasei, L. \& and E. Chitando (eds.): Faith in the city: The role and place of religion in Harare. Uppsala: Swedish Science Press.

Halbfinger, D.M. 2020. Coronavirus in Israel: Virus soars among ultraorthodox Jews as many flout Israel's rules. The New York Times. May 7, 2020. Available at: https://www.theguardian.com/world /2020/apr/06/calls-to-seal-off-ultra-orthodox-areas-adds-tension-toisraels-virus-response. (Accessed on July 13, 2021.)

Hong, B.A. \& P.J. Handal 2020. Science, religion, government and SARSCoV-2: A time for synergy. Journal of Religion and Health June 2: 16. doi: 10.1007/s10943-020-01047-y.

Ibrahim, M. 2020. Corona virus is a ghost from the West: Conspiratorial explanations of Covid-19 pandemic among the religious leaders in Nigeria. TRAFO blog for Transregional Research. Available at: https://trafo.hypotheses.org/24074. (Accessed on July 12, 2021.) 
Kangwa, J. 2016. Pentecostalisation of mainline churches in Africa: The case of the United Church of Zambia. The Expository Times 127, 12: 573584.

Kgatle, M.S. 2016. Sociological and theological factors that caused schisms in the Apostolic Faith Mission of South Africa. Studia Historiae Ecclesiasticae 42, 1: 1-15.

Kgatle, M.S. 2018. Social media and religion: Missiological perspective on the link between Facebook and the emergence of prophetic churches in Southern Africa. Verbum et Ecclesia 39, 1: 1-6.

Kirby, B., J. Taru, \& T. Chimbidzikai 2020. Pentecostals and the spiritual war against coronavirus in Africa. The Conversation. April 30, 2020. Available at: https://theconversation.com/pentecostals-and-thespiritual-war-against-coronavirus-in-africa-137424. (Accessed on August 15, 2021.)

Kowalczyk, O., K. Roszkowski, X. Montane, W. Pawliszak. B. Tylkowski, \& A. Bajek 2020. Religion and faith in a pandemic of COVID-19. Journal of Religion and Health 59: 2671-2677.

Lategan, B. 2009. New Testament hermeneutics (Part II): Mapping the biblical hermeneutics. In Du Toit, A. (ed.): Focusing on the message: New Testament hermeneutics, exegesis and methods. Pretoria: Protea.

Lumberas, S. \& L. Oviedo 2020. The pandemic and its influence on the relationship between science, religion, and theology. ESSSAT News and Reviews 30: 1-12.

Makandiwa, E. 2020a. Special Sunday service with Emmanuel Makandiwa. YouTube. April 12, 2020. Available at: https://www.youtube.com/ watch?v=0shN-4jfXxY. (Accessed on August 24, 2021.)

Makandiwa, E. 2020b. Coronavirus prophecy - Prophet Emmanuel Makandiwa (original). YouTube. March 14, 2020. Available at: https:// www.youtube.com/watch?v=6WCQhuh3KDg. (Accessed on August 22, 2021.)

Maxwell, D. 1995. Witches, prophets and avenging spirits: The second Christian movement in North-East Zimbabwe. Journal of Religion in Africa 25, 3: 309-339.

Maxwell, D. 2006. African gifts of the Spirit: Pentecostalism and the rise of a Zimbabwean transnational religious movement. Harare: Weaver Press. McVean, A. 2019. 40 years of human experimentation in America: The Tuskegee Study. McGill: Office for Science and Society. January 25, 
2019. https://www.mcgill.ca/oss/article/history/40-years-humanexperimentation-america-tuskegee-study. (Accessed on August 22, 2021.)

Meyer, B. 2004. Praise the Lord: Popular cinema and pentecostalite style in Ghana's new public sphere. American Ethnologist 31, 1: 92-110.

Morsy, H., L. Balma, \& A.N. Mukasa 2020. Not a good time: Economic impact of COVID-19 in Africa. Working Paper Series No. 338, African Development Bank, Abidjan, Côte d'Ivore.

Mujinga, M. 2021. Technologization of religion: The unstoppable revolution in the Zimbabwean mainline churches. In Okyere-Manu B.D. (ed.): African values, ethics, and technology. Cham: Palgrave Macmillan.

Müller, L. 2020. Christians in Africa. In Chryssides, D.G. \& S.E. Greggs (eds.): The Bloomsbury handbook to studying Christians. New York: Bloomsbury Academic.

Nel, M. 2015. Attempting to define a Pentecostal hermeneutics. Scriptura 114, 1: 1-21.

NewsdzeZimbabwe. 2021. Covid kills Gweru nurse. Available at: http://www.newsdzezimbabwe.co.uk/2021/07/covid-kills-gwerunurse.html. (Accessed on August 22, 2021.)

Olson, R.E. 1999. The story of Christian theology: Twenty centuries of tradition \& reform. Leicester: Apollos.

Oyakhilome, C. 2020. Coronavirus is a ghost from West. YouTube. April 18, 2020. Available at: https://trafo.hypotheses.org/24074. (Accessed on July 11, 2021.)

Pavari, N. 2021. The role of Pentecostal church leadership to the COVID-19 pandemic in Zimbabwe. Global Journal of Management and Business Research: An Administration and Management 21, 5: 1-7.

Public Health. 2020. COVID-19 prevention, containment and treatment (national lockdown) (amendment) order, 2020 no. 5. Harare: Government of Zimbabwe. URL: http://zimlii.org/zw/legislation/si/ 2020/99.

Rance, D. 2009. Fulfilling the apostolic mandate in apostolic power: Seeking a Spirit-driven missiology and praxis. Paper Presented at the $38^{\text {th }}$ Annual Meeting of the Society for Pentecostal Studies, 1-25.

Sande, N. 2016. Christian faith and sexual orientation in the context of HIV and AIDS in Zimbabwe. Alternation 23, 2: 31-43. 
Sande, N. 2017. Faith and equality: Rethinking women in leadership positions in Pentecostalism. Journal of Gender and Religion in Africa 23, 1: 50-62.

Sande, N. \& B. Maforo 2021. Pastoral ministry from the margins: Pastors' wives in Apostolic Faith Mission in Zimbabwe. Studia Historiae Ecclesiasticae 47, 2: 1-14.

The Conversation. n.d. Pentecostals and the spiritual war against coronavirus in Africa. Available at: https://theconversation.com/pentecostals-andthe-spiritual-war-against-coronavirus-in-africa-137424. (Accessed on August 24, 2021.)

Togarasei, L. 2010. Churches for the rich? Pentecostalism and elitism. In Togarasei, L. \& E. Chitando (eds.): Faith in the city: The role and place of religion in Harare. Uppsala: Swedish Science Press.

UFIC. n.d. Update - Emmanuel Makandiwa's Coronavirus (Covid-19) prophecy - summary of events. Available at: http://www.ufiministries. org/update-emmanuel-makandiwas-coronavirus-COVID-19-prophecysummary-of-events/. (Accessed on August 24, 2021.)

Ukah, A. 2020a. Prosperity, prophecy and the COVID-19 pandemic: The healing economic of African Pentecostalism. Pneuma 42: 430-459.

Ukah, A. 2020b. Sacred surplus and Pentecostal too-muchness: The salvation economy in African megachurches. In Hunt, S. (ed.): Handbook of Mega-churches. Leiden: Brill.

UNDP (United Nations Development Program). 2020. Policy brief: A preliminary assessment of the socio-economic impact of Coronavirus (Covid-19) on Zimbabwe. Geneva: UNDP.

Vander Zanden, J.W. 1988. The social experience: An introduction to society. New York: Random House Inc.

Vengeyi, O. 2011. Zimbabwean poverty is man-made! Demystifying poverty by appealing to the prophetic book of Amos. Scriptura 107, 1: 223237.

Worldometer. 2021. Zimbabwe Coronavirus cases. Available at: https://www.worldometers.info/coronavirus/country/zimbabwe/.

(Accessed on August 8, 2021.)

ZIMSTAT. 2019. Updated 2012 population census projection report. Woldometer 2021. Zimbabwe Coronavirus cases. July 8, 2021. Available 
https://www.worldometers.info/coronavirus/country/zimbabwe/. (Accessed on July 27, 2021.)

Dr Nomatter Sande

Research Institute for Theology and Religion UNISA, Pretoria pastornomsande@yahoo.com 